\title{
Cumhuriyet'in 100. Yılında Türk Üniversitelerinden Beklentiler
}

\author{
Tuğba TEKİN*
}

\section{SUNUM}

Dünyada üniversitelere yüklenen çok çeşitli görevler vardır. Bunlar, bilim ve teknolojiyi yakından takip etmek ve ülke çıkarları doğrultusunda kullanmak, her türlü gelişmelere duyarlı olan topluma bu gelişmelerin nedenleri ve sonuçları hususlarında öncü olmak, evrensel ve yöresel kültür mirasını korumak ve geliştirmektir. Kısaca düşünmek, araştırmak, uygulamak diye sloganlaştıracağım bu misyonlar, Türk üniversitelerince ne kadar anlaşılıyor, ne kadarı yerine getiriliyor. Türk üniversiteleri tüm dünyadaki çağdaş üniversite arayışlarına ne kadar katılıyor? Bilimsel gelişmelerin neresinde duruyor; bu bilimsel gelişmeleri takip ediyor mu içselleştirebiliyor mu? Gelişmekte olan ülkelerden biri olan Türkiye Cumhuriyeti'nin üniversitelerini başka hangi görevler bekliyor?

Üniversitelerimizin idari, mali, sosyal, politik bir çok sorunla boğuşması, küresel dünyada diğer ülkelerin üniversiteleri ile rekabet edebilmesi açısından büyük bir dezavantaj yaratıyor ama bu onların kötümser ve durağan olmasını kabullenir kılmaz.

Başını kapatanları üniversiteye alalım mı almayalım mı, rektörü seçelim mi atayalım mı? Böyle güncel ama yapıcı çözüm getirilemeyen sorunlar yüzünden, belki üniversite gençliği ile üniversite adayı gençliğinin sorunlarına yeterince değinilmiyor.

Gerçek kişilerden edindiğim bilgiler doğrultusunda üniversite gençliğinin sorunlarını ve bu sorunlarına çözüm önerileri ışığında üniversitelerimizi yurtdışında da cazip hale getirecek, çağdaşlaşmasını sağlayacak yapılanmaların neler olabileceğini anlatmaya çalışacağım. Umarım Cumhuriyetimizin 100. yılını daha da coşkulu kullanmasına vesile olacak çözüm önerilerine katkım olur.

Üniversite gerçeğimizi sorgulamaya en temelden başlamak adına 1 . bölümde sınava ortaöğretim sistemimizdeki bozukluğa ve çözüm önerilerime

• Ankara Üniversitesi, Siyasal Bilgiler Fakültesi, İşletme Bölümü, 3. Sınıf Öğrencisi. 
kısaca değindim. 2. bölümde ise gençlerin gözünden üniversitelerimizi değerlendirdim ve bu değerlendirme ş̧ığında üniversitelerimizin çağa ayak uydurması için gerçekleştirilmesi gereken yapılanmaları anlattım.

\section{BÖLÜM}

\section{TÜRK ÜNIVERSITTELERİ 2023'e HAZIR MI?}

2023'de yükseköğretimimizin vizyonu; yükseköğretime kitle öğretim niteliği kazandırmak, öğrencilere ilk yıllarda dünyanın değişen koşullarına uyum sağlayabilecek esnek ve açık programlar izletmek ve onları sonraki yıllarda uzmanlaşmaya yönlendirilmek olmalıdır. Yükseköğretim kurumlarımızın üretken hale gelmesi için, hazır yiyici ve ezberci eğitim sunan ortaöğretim kurumlarımızın düzeltilmesini beklemek zaman ve para kaybından başka bir şey değildir. Yükseköğretimimizin 2006'da sınav mevzuatının değiştirilmesiyle (10. ve 11. sınıf konularının eklenmesiyle) yükseköğretime başlayanların daha bilgililer arasından seçileceği umudu uyansa da bu akademik eğitim için gerekli donanımlı öğrencilerin yetiştiğini göstermez.

Gençlerimizi temel eğitimde başlaması gereken bilimsel ve kişiye özel bir yönlendirmeden geçirmeden, ilgi ve yeteneklerini göz önüne almadan seçici değil sıralamacı bir sınav sistemiyle yükseköğretim kurumlarına yerleştiriyoruz. Gençlerimiz üniversitenin bilim, sanat, kültür yaratmak felsefe ve araştırma yapmak gibi asıl misyonlarına nail olmaktan çok bir şekilde para kazanabileceği meslek diploması almak umuduyla yükseköğretim kurumlarına yığılıyor.

Yükseköğretimimizin manzarası bu olmamalı. Uzun vadede gençlerin, bilimsel rehberlik metotlarıyla meslek ve genel liselerden birine, sonrasında da ilgi ve kabiliyetleri doğrultusunda, bilim yapmak ya da meslek edinmek amacıyla isabetli alanlara yerleşebilmesi, üniversitelerimizin donanımlı ve hevesli öğrenciler edinmesi için şarttır. YÖK taslak raporunda da belirtildiği gibi, aşamalı sınav sistemi kısa vadede doğru öğrencinin doğru alanda öğrenim görmesi için uygulanabilir bir çözümdür. Ancak bu çözüm önerisi her fakültenin özelliğine göre ayrı ayrı sınavlarla öğrenci alması şeklinde daha da iyi hale getirilebilir. Bu sayede:

- Sınav soruları daha seçici olacak. Sınavlarda ileri düzey matematik, fizik, biyoloji, tarih sorulacağı için öğrenci ilgilendiği birkaç derse yoğunlaşacak, bu sayede öğrenciler okula bağlı hale gelecek. Çünkü ileri kimya, uygulamalı fizik, tarih II gibi adlar alan seçmeli derslerle öğrenci laboratuar, kütüphane olanaklarından daha fazla yararlanarak bilgisini arttırmak zorunda bırakacak. Böylece orta erimde (vadede) dershaneciliğin, ezberciliğin önüne geçilecek.

- Fakültelere göre özelleştirilmiş sınavların dilediği kadarına girmekte serbest olan öğrenci, ÖSS'nin öğrenciyi ve tercihleri sıralama mantığından 
ziyade daha tatmin edici bir seçim olanağına kavuşacak. Doğru seçimle yerleşmiş öğrenciler üniversitede boşluğa düşmeyecek, hayal kırıklığı yaşamayacak, üniversitesini sahiplenecek ve daha çok çalışacaktır. Neticede üniversitelerimizin kalitesi artacaktır.

\section{Üniversitelerimizi Körelten Yı̆̆̆lma}

Türkiye'de üniversitelerimiz bir gerçekle yüzleşmek zorunda. Mesleki eğitimin ortaöğretimde yetersiz verildiği ülkemizde, üniversitelerimizi bir şekilde diploma alma kapıları haline getiren uygulamalardan vazgeçilmelidir. Uygulamalardan biri otomatik haklardır ki üniversitelerin misyonlarına zarar verir. Askerlik hizmetinde diplomanın sağladığı avantajlar, batılı ülkelerde olduğu gibi meslek yeterlilik sınavlarının olmaması yüzünden diploma alan kişinin meslek sahibi olduğu sayılması, bilginin sürekli eskidiği göz önüne alınmadan diploma sahibinin diplomada yazan mesleği kendini yenilemeden yıllarca yapabilmesi, üniversiteleri meslek yüksek okulları haline getiriyor. Oysa bu ayrım iyi yapılmalı.

\section{Yığılma Nasıl Önlenir}

Meslek liseli çıkışların yöneleceği ve meslek edinmeleri için her türlü ihtiyacı karşılanmış MYO'ları birim maliyeti düşük olması sebebiyle yükseköğretim okullaşma oranını daha kısa sürede arttırır. Bu sebeple MYO cazip hale getirilmeli, yurt geneline yayılmalı. Mevcut üniversitelerin eksiklikleri karşılanmadan, akademik kadro ihtiyacının nasıl karşılanacağı öngörülmeden, siyasi kaygılarla yüksekokul sayısının artırımı yığılmaya çözüm olmadığı gibi yüksekokullarımızın kalitesini, misyonunu, cazibesini kırmaktan öte bir işe de yaramaz. Nitekim Atatürk "kıymetsiz talebenin ilk sene cesareti kırılmalıdır" derken; akademik yükseköğretimi kaldıracak çalışma azminde olmayanların en başta doğru yönlendirilmelerinin gereğine işaret etmiştir.

Atatürkün "Memleket evlad,, her tahsil derecesinde ekonomik hayatta iş yapabilir, etkili, verimli ve başarılı olacak şekilde donatılmalıdır" emelinin gerçekleşmesi yükseköğretimde okullaşma oranının arttırılmasına ve doğru politikaların izlenmesine bağlıdır.

\section{BÖLÜM}

\section{CUMHURIYETIMIZIIN 100. YAŞ GÜNÜ KUTLU OLSUN}

Örgütlenmelerin kuruluş yıldönümlerinin kutlanmaları, insanlara yeni icraatlar için umut verir. Emperyalizme karşı dünyada takdir gören bir mücadelede sonunda bağımsızlığını kazanan Türkiye Cumhuriyeti'nin ilk on, elli, seksen yıllık kazanımları, bölgesel ve küresel etmenler de göz önüne alınarak değerlendirildiğinde 100. yılında ulaşılması hedeflenen reformlar için önemli fikirler verecek ve şevk uyandıracaktır.

Atatürk'ün kurduğu cumhuriyetin nüfusu 13 milyon civarında, okuma yazma oranı yüzde 14, ihracatı 50 milyon, ithalatı 90 milyon dolar dolayında 
seyrediyordu. Bugün ise 70 milyon nüfuslu ülkemizde okuma yazma oranı yüzde 90 , ihracat 65 milyon, ithalat 100 milyon dolar civarındadır. Tek üniversiteli Türkiye, 80 üniversiteye bir doktorlu Türkiye 80 bin doktoluya ulaştı. Her ne kadar şimdiki siyasi, ekonomik, sosyal seviyemizden sitemkar olsak da Mustafa Kemal in dediği gibi "Türk ulusunun ve onun değerli ordusunun bir ve beraber olarak azimkarane yürüyüşü" ile başlayan bu yoktan var oluş süreci; hayıflanmalardan, nihayetsiz kavgalardan çok, bilimsel açılımlı çözüm önerileri ve uygulamalarla Cumhuriyetimizin 100 . yaş gününde verdiği coşkuyla artan hızla devam etmelidir. Bu nedenle 2023 tarihi, ulusal hedeflerimizi yenilemenin ve daha büyük hayallere birlikte yürümenin simge tarihi olacaktır.

Çă̆ımız gelişmelerine yön veren devletler Arap devletleri gibi zengin ülkeler değil, bilim ve teknolojiyi geliştiren, kullanan ABD, Almanya, Japonya gibi ülkelerdir. Türkiye Cumhuriyeti bu devletler arasında yer almayı hedefliyorsa on yıllar süren politik görüşmelere bel bağlamamalıdır. Gerek devlet gerekse özel sektör kurumlarıyla bilim üretmeye birincil dereceden önem vererek, teknoloji üreten araştırma birimleri ve dünyadaki gelişmiş sistemleri sürekli olarak inceleyen rapor eden ekipler kurarak hedefine ulaşmalı. Bahsi geçen kurumlar üniversitelerimiz ile onlara bağlı enstitülerimiz ve teknoparklarımızdır. Cumhuriyetimizi yaşatacak ve koruyacak olan biz gençler, Atatürk'ün emanetini muhafaza etmek, vasiyetini daha iyi yerine getirmek için yükseköğretimdeki bozukluklar arasında sesimiz duyulmasa da, haklarımız gözetilmese de mevcut imkanlar dahilinde en iyisini yapmak için belki de dünyanın hiçbir yerinde gençlerin çekmediği cefayı çekiyoruz, çekmeye hazırız.

Akademik yükseköğretim görebilecek öğrencilerin yönlendirilmesinde başlayan eksiklikler yüzünden çıkan sorunlar, üniversitelerimizin gençlerimizi yüksek öğretime hazırlayıcı önlemler almasını zorunlu kılıyor.

\section{Teknoloji Destekli Eğitim}

Ortaöğretimde araştırma, yorumlama, tartışma eksikliğiyle ezberci ve hazır yiyici nitelik kazanmış kötü temel üzerine üniversitenin asıl misyonlarından, üretken ve sorgulayıcı özellikli birey yetiştirmenin zorluğu aşikârdır. Ama bu kötümser tablo üniversitelerimizin sineye çektiği bir gerçek olmamalıdır. Çă̆ın gelişmelerini takip eden, anlayan ve ona ayak uydurmasını becerebilen bir nesli, yapılacak düzenlemelerle üniversitelerimizde diplomalarıyla beraber mezun etmek mümkün olabilir. $\mathrm{Bu}$ düzenlemelerden biri de kuşkusuz "akıllı öğretim sistemlerinin" kullanılmasidır.

Üniversitelerimiz gelişen teknolojiyi derslerin daha kısa sürede ve daha anlaşılır olması için kullanmıyor. Oysa bilgisayar, ved çalar, kaset gibi herkesin kolayca ulaşabileceği aygıtlarla dersler, ders programlarına, dersliklere sıkışmaktan kurtarılabilir. On yıllardır alışagelmiş şekliyle öğrencinin sırada, öğretmenin de kürsüde olduğu sistemin bozulup, derslerin 
animasyonlarla, sinevizyonla daha kısa sürede öğretilmesi için teknolojinin kullanımı başta çok maliyetli olacağı gerekçesiyle hayalî bulunabilir. Öğretmenler, alışkanlıklarından vazgeçmek istemeyebilir. Ama hem öğrenciye başka alanlarda da kendini yetiştirmesi ve hem de öğretmene araştırma yapması için zaman ve enerji tasarrufu sağlayacağı için uzun vadede teknolojiye yatırım maliyetleri, sağladığı getirinin çok altında kalacaktır. Üniversitelerimizin her bölümünde vakit kaybetmeden "akıllı öğretim sistemleri” geliştirilmelidir. Örneğin Siyasal Bilgiler Fakültesi İşletme Bölümü derslerinden kuramsal kavramlar haftada üç veya dört saat olmak üzere sınıflarda işlenirken herkes çok sıkılıyor. Öğretmenin yılların verdiği bıkkınlıkla ders anlatması gözden kaçmıyor. Oysa üç saatte anlatılan kavramlar, kuramlar ses kayıt cihazına doldurulduktan sonra, rapor haline getirilse bile üç-dört sayfayı geçmez. Bu üç-dört sayfanın okunup anlaşılması öğrencinin bir saatten fazla zamanını almaz. Öyleyse neden boş yere vakit kaybediliyor, mekân işgal ediliyor. Öğretmenler dersin içeriğini anlatan raporlarını öğrenciye her türlü imkânlarla ulaştırmalı, ders saatleri (kredileri değil) böylece azaltılmalı mevcut kılınacak ders saatinde ödevler verilmeli, tartışmalar yapılmalıdır. Yüzyıllar önce ortaya atılan teorileri öğrencinin öğrenmesi için sınırlı mekâna ve zamana sıkışmanın anlamı yok. Kendi bölümümden yola çıktığım bu gerçek sosyal, fen, eğitim, sağlık bilimlerinin okutulduğu tüm bölümlerin birçok ders işleniş şekli için geçerlidir. Bu yüzden akıllı öğretim sistemleri birçok dersin öğretiminde kullanılabilir.

"Üniversiteye bunları dinlemeye mi geldik?", "bu yavan şeyleri dinlemek için mi oturuyoruz" gibi memnuniyetsizlikler yüzünden oluşan doyumsuzluk ve derslerden soğuma basit ve etkin öğrenci odaklı öğrenim metotlarıyla kolayca çözülebilir.

Akıllı eğitim sistemi diye tabir ettiğim teknolojinin her türlü nimetinin eğitimde kullanıldığı sistem, öğrenmenin verimini arttıracaktır. Herkesin kapasitesinin farklı olduğu sınıfta öğretmen ortalama seviyedekilere göre ders anlatmak zorundadır. Bu durumda dersi çabuk kavrayanlar zaman kaybederken, geç kavrayanlar eksikliklerini gidermek için çoğu zaman hocaya tekrar anlattırmazlar. Bilgisayarının başında animasyonla dersi dinleyen genç ise dersi istediği kadar tekrarlatarak bilgi seviyesini sınıf ortamında yapabileceğinden daha çok arttırır.

\section{Disiplinler Arası Esneklik}

Dünya'da yükseköğretimin öncüleri sayılan ABD'de son 15-20 yıldır, gözlenen gelişmeye göre 4 yıllık lisans eğitimi sırasında öğrencilere alanlarındaki tüm bilgiyi öğretmek imkansızdır, gereksizdir sonucuna varılmıştır. Önemli olan kendi alanındaki temel kavramları iyi bilen bilgi kaynaklarına ulaşabilen, analitik düşünme yeteneği gelişmiş ve takım çalışması yapabilen mezunlar yetiştirmektir.

Yapılan tahminler ışı̆̆ında diyebiliriz ki üniversite mezunlarının 21. yüzyılda hayatları boyunca yaklaşık 4 farklı işte çalışacaklar. Bilimin 
disiplinler arası bir boyuta geldiği dünyamızda, hangi programdan mezun olanların nerede çalışacağının önceden bilinmesi söz konusu değildir.

Disiplinler arası esneklik uygulaması öğrencilere daha geniş yelpazede çalışma olanağı yaratacağı için iş bulma endişesini, yerleştiği bölüme hapsolma psikolojisinin yarattığı kavramsallığı ortadan kaldıracaktır.

Bu gelişmeler programların esnek yapıda olmasını gerekli kalıyor. Tüm üniversitelerimizde anadal-yandal uygulaması yaygınlaştırılmalı, öğrenciler uygulama ve yönetmelik hakkında bilgilendirilmelidir. Örneğin işletme bölümü öğrencisi Fransız Dili ve Edebiyatı konusunda da uzmanlaşmak isteyebilir. 2023'te Web Tabanlı Uzaktan Eğitim modelinin yaygınlaşması, derslerin video-kayıt olanaklarıla daha kısa zamanda sunulması ve öğrenilmesi sayesinde gençler kendilerini birkaç alanda geliştirme olanağına kavuşabilirler.

\section{Fakülte İçi Esnek Geçişler}

Gençlerin kendini tanımadan bir meslek seçimine zorlanmasıyla düştüğü bocalama evresi üniversite tahsilinin ilk yıllarında da devam ediyor. ÖSS'ye katılan öğrencilerin yaklaşı $1 / 5$ 'inin önceki yıllarda bir programa yerleşenler olması, eğitim bütçesinde ciddi kaynak israfı doğuruyor, genç açısından da boşa emek ve zaman harcaması anlamına geliyor. Gencin en verimli olacağı programa yerleşmesi temenni edilendir. Bunun için aynı yüksek öğretim kurumu içinde bir programdan diğerine geçişin esnek hale getirilmesi öğrenci memnuniyetsizliğini azaltacak, motivasyon ve başarısını ise arttıracaktır. Ders notları düşük öğrencilerin \%50'den fazlasının yerleştiği bölümden memnun olmayanların olması, tekrar sınava girenlerin 1/5'inin daha önce bir yüksek öğretim programına yerleşmiş olanlar olması bu konuda yapılması gereken düzenlemelerin aciliyetini gösteriyor.

Öğrenciyi en uygun programa yerleştirme hususunda ÖSS'de yapılabilecek değişikliklere değinmiştim. İzlenebilecek diğer bir yaklaşım, ÖSS sonucunda öğrencileri belirli bir program yerine fakülteye yerleştirmek olabilir. İlk iki yılda temel dersler alarak temel kavramları öğrenen öğrenci, tercihini 3. sınıfta yapmalıdır. İngiltere'de yapılan araştırma, tercihlerin bilinçsiz yapılması nedeniyle, öğrencinin isteyerek başlamış oldukları programlardan bile memnun olmadıklarını ortaya koymuştur. ABD'de uygulama, öğrencinin ilk iki sene doğa bilimlerinden sosyal bilimlere çoğu seçmeli olan dersler alması, 3 . sene belli bir programa yerleşmesidir.

\section{Üniversitelerimizde Dil Eğitimi}

2023'lerin yükseköğretim mezunlarından dünya gelişmelerine duyarlı ve onların takipçisi olması beklenir. Bu yüzden okuduğunu, duyduğunu anlamaya yeterli olacak, en azından bir yabancı dilde donatılmalıdır. Bu nedenle uzun vadede ortaöğretimden gelen öğrencilerin yabancı dil sorununu çözmüş olarak yükseköğretime başlamaları sağlanmalıdır. ÖSS'de yığılmanın önlenmesi, seçiciliğin arttırılması hem de zorlaşan akademik 
eğitimden ziyade mesleki eğitim tercihinin cazip hale gelmesi açısından dil sınavları üniversiteye girişte belli bir orana getirilebilir. Kısa vadede üniversitelerde öğrencinin dil bilgi donanımını arttırmak için belirlenecek hedeflerin yapıcı olacağı kanaatindeyim. Siyasal Bilgiler Fakültesi İngilizce dersi eğitiminin çok yetersiz olduğunu söyleyebilirim. Ülkemizin yetişmiş maliyeci, diplomat, ekonomist, siyasetçi ihtiyacını karşılamak misyonunu üstlenen en eski ve en prestijli okulumuzun tercihlerde İngilizce eğitimi daha iyi olan okulların altında kalması, değişen talebin hangi doğrultuda olduğunun tartışmasız kanıtıdır. Yüksek öğretim dil okutmanları arzını önümüzdeki yıllarda hızla arttırmalıdır.

Öğrenciler, dil derslerini lisans dersleri kadar önemsemiyor, katılım yoklamalarla sağlanmaya çalışılıyor. Okutmanların dersleri verimsiz işlemesi, dersin amacına uygun işlenmemesi, öğrencide motivasyon bozukluğuna sebep oluyor. Oysa mezunların çoğu dil yetersizliğinden muzdarip. İktisat, muhasebe, hukuk gibi lisans derslerindeki eksiklikler her zaman giderilme olană̆ına sahipken, zamanında gırgır şamatayla geçen İngilizce derslerinin telafisi maliyetli, zaman alıcı oluyor.

Yabancı dille eğitim tartışması güncelliğini hep koruması bakımından değil uzun vadede bilim politikamızı, gelecek nesillerin düşünme ve kültür alışkanlıklarını yakından ilgilendirmesi sebebiyle değinilmeden geçilmemesi gereken sorunlardandır. Yabancı dille eğitim veren yükseköğretim kurumlarının deneyimleri uzun yıllara dayansa bile bu konuda esnek bir tavır sergileyemiyor. Örneğin, Türkiye Ekonomisi, Türkiye İktisat Tarihi, Türk Hukuk Sistemi gibi dersleri bile yabancı dilde verme çabasında oldukları ve birçoğu Türkiye ile doğrudan ilgili lisansüstü tezlerin yabancı dilde yazılmasının yarattığı anlamsızlığı görmezden gelmek, üniversitelerimizin topluma öncü olma misyonuyla bağdaşmaz. Fen Bilimleri öğrencilerinin ortak kanaati; dersler anadille eğitim verilseydi daha detaylı öğrenecekleri yönünde. Uzun erimde oluşturulması gereken sistem şöyle olmalıdır: Eğitimin anadille yapılarak sıkı bir akademik birikiminin bunun yanında kaliteli mesleki dil eğitimiyle araştırma yapabilmeyi sağlayacak terimsel yabanc1 dil kelime haznesinin ve yabancı dilde düşünme yetisinin kazandırılması sağlanmalı. Mesleki dil dersi kredisi 4 veya 5 olmalı ve bu derslerde öğrenci anadiliyle öğrendiği akademik ve mesleki bilgilerini yabancı dilde yazılmış makalelerle pekiştirmeli, sorgulamalı. Lisans eğitimi sonunda mükemmel bir akademik donanım ve dil hedeflenmeli.

Orta erimde üniversiteden mezun olacak öğrencilerden geçerliliği kabul edilen lisans düzeyi dil sınavlarında belli puan barajı istenebilir.

Gelişmiş $\mathrm{AB}$ ülkelerinin eğitim dillerinin kendi anadilleri olduğu, ülkemizde yabancı dille eğitime talebin bu kadar yoğun olmasının ardından kültür sömürüsünün yattığı gerçeklerine değinmeye gerek yok. Tarih her şeyi anlatıyor. Tarih, ibret almayanlar için tekerrürden ibarettir. Farsça'nın, Arapça'nın dilimize ettiğini, İngilizce'den de görmeden uyanırız umarız. 


\section{Aktif, Sosyal Öğrenci}

Öğrenciler belki de eski alışkanlıklarından ötürü sunulan bilgiyle yetiniyor. Birçoğunun dünya görüşü yok. Sosyal aktivitelere, öğrenci derneklerine katılım bir üniversite gençliğinden beklenilen aksine düşük seviyelerde olduğu, boş zamanların "kahve kültürüyle" değerlendirildiği hep eleştiri konusu olmuştur. Gençler de bu eleştiriye ders saatlerinin fazlalığından şikâyet ederek cevap verirler. Ders saatlerinin, neredeyse tüm günü kaplayan fazlalığı, değindiğim yeniliklerle hafifletilebileceği gibi öğrenciyi sosyal hayata katılımını teşvik eden yapılanmalara da gidilebilir. ODTÜ, Hacettepe örneğinde olduğu gibi merkez kampüste yer alsın-almasın öğrenci klüplerine oda tahsis edilmelidir. En aktif, en icraatçı, en başarılı öğrenci klüpleri ödüllendirilerek projelerinin artırımı teşvik edilmeli. Gerekirse kulüplere maddi destek verilmeli veya kendilerini finanse edecek olanaklar sağlanmalı. Başka fakültelerde, çeşitli öğrenci topluluklarının maliyeti artırdıkları, mekanı işgal ettikleri gerekçeleriyle etkinliklerinin kısıtlandığını duyuyoruz. Mülkiye Sinema Kulübü haftalık film gösterimlerine devam etmek için ellerinden alınan amfi ve projektör için imza toplamak zorunda kalmıştı. Daha sonra imkânlar tekrar sağlansa da gösterimlerin sekteye uğraması ilgiyi dağıtmıştı. Üniversiteye gelen öğrenci sınavlara girip-çıkan, ödev hazırlayan insan tipi değildir. Köklü üniversitelerimiz gibi tüm Türk üniversiteleri evrensel, özerk ve özgür ortamlar yaratarak gençlerin ortaöğretimde farkına varmadıkları yetenekleri keşfetmelerine fırsat vermelidir. Bu konuda SBF sınav sistemi müfredatı öğrencilere boş zaman fırsatı vermiyor. Bazen talihsizlikler neticesinde kötü geçen finalin hukuki kısıtlama yüzünden bütünleme sınavıyla veya hocaların keyfi nedenleri yüzünden yaz okuluyla telafisinin olmaması, kredi sınırlaması sebebiyle okulu uzatma tehlikesi yaratması acaba hangi akademisyenin vicdanını rahatsız etti.

Bazı Avrupa üniversitelerinde (İngiltere, Almanya, Fransa, İspanya gibi ülkelerde) güçlü öğrenci birlikleri var. Öğrenci parlamentosu, üniversite yönetimine katılacak delegeleri belirler, öğrenci sorunlarını iletir, yayın çıkartır, yeni gelenlerin üniversiteye uyumlarını sağlayacak etkinlikler düzenler. Üniversitelerimizde de yönetimce desteklenen öğrenci toplulukları olsa; belki de idare ile olan sürtüşmeler sokak gösterileri boyutunu almadan çözüme gider, idari mahkemelerin yükü azalır, özellikle kırsal yerlerden gelip uyum sağlayamayan öğrencilere yardımcı olunurdu.

Üniversite kapısına kadar çok az eğitilen genç yetersiz sosyal olanakları ve okuma eğitiminin gelişmemesi yüzünden kişilik ve kimlik bulanımı yaşıyor, işe giremiyor, kişiliksiz bir kuşak oluşuyor. ODTÜ, İTÜ, Boğaziçi bu konuya biraz daha duyarl.

\section{Üniversite Kültür Üretmelidir}

Her üniversitenin iyi kötü bir imajı vardır ve öğrenci üniversitesini severse ona sahip çıkar. Türkiye'de üniversitelerin gelenek haline 
getirecekleri şenlikler, bayramlar, kutlamalarla hem senenin yorgunluğunu atar, hem bir senenin değerlendirmesini yapar, hem de eski mezunlarla öğrenciler tanıştırılarak üniversiteye has nesil birlikteliği oluşturur. Mülkiye İnek Bayramı, bir geleneği devam ettiren zenginleştirilmesi gereken üniversite kültürlerimizdendir. Koç Üniversitesi gibi tanınmış bir kurumumuzun eğlence ve gezi kültürünün olmaması öğrenciler arasında şikâyete sebep oluyor. "O kadar para ödüyoruz her sene Kenan Doğulu konserinden başka bir etkinlik olmuyor" diye ifade ediyorlar. Genel itibariyle üniversitelerimizde tertiplenen bahar șenliklerinin konser havasından öte gitmeyen görüntüsü kültür yaratmaktan uzak. Bu şenliklerde öğrenci kulüpleri ve çalışmaları tanıtılarak, başarıları ödüllendirilerek, bir önceki senenin mezunlarından derece yapanlara plaket verilerek başarılar teşvik edilmeli ve duyurulmalıdır. Böylece belki başaranı kıskanmayı değil onun yanında olmayı öğrenmiş oluruz. Akıl oyunlarında öğretim görevlileri takdir ettikleri öğretim görevlisi arkadaşını kalemlerini verme geleneğiyle kutluyorlardı. Bizde acaba bu kültür var mı yoksa bir şeyler yapmak isteyenlerin kalemlerini mi alıyoruz. Yenilikçiye, azimliye destek olmayı öğrenmek için geç değil.

Var olan kültür hazinemizi tanıtmak ve zenginleştirmek üniversitelerimize düşen bir diğer görevlerindendir. Ankara Üniversitesi Kültür Haftası Etkinlikleri ile öğrencilerin etkinliklerinin şehre dinamizm getirmesi, taşra üniversitelerimize örnek teşkil etmeli. Bu tür kültür haftaları Anadolu'daki üniversitelerimizde teşvik edilerek öğrenci-yöre halkı kaynaşması sağlanmalıdır. Üniversitenin bulunduğu yöreyle bütünleşmesi ve oranın sosyo-kültür seviyesinin artmasına vesile olması beklenen misyonlarındandır. Kampüsüne kapanmamış Anadolu üniversitelerimizin bilim, sanat yapmanın yanı sıra; yörenin geri kalmışlık göstergeleri olan kan davası, töre cinayetleri, berdellik adeti, kadınların aşağılanması gibi 21 . yüzyıla ve Cumhuriyetin 100. yaşına yakıșmayan çağdışı uygulamalardan, inançlardan kurtulması için büyük vazifeler de düşüyor. Hayalimizdeki gibi kampüsundan çıkmış bir akademisyenin köy kahvesinde yöre halkıyla muhabbeti, yörenin yadırgamayacağı şekilde giyinerek bayanların mekanına girip onlara bilmedikleri şeyleri anlatan kız öğrenciler olsaydı birçok tabu yıkılırdı. Yöre halkı, üniversitesini kabullenir, kız öğrencileri geleneklerine uymadıkları gerekçesiyle dışlamaz, öğrencileri sadece müşteri olarak akademisyenleri de hiçbir şey bilmeyen çok bilmişler olarak görmezdi.

Anadolu da okuyan gençlerin sorunları arasında kendilerine kiralık ev bulmada çıkarılan zorluklar ve yükseltilen fiyatlardan başka yeterli sosyal, sportif alan olmaması da vardır. Anadolu üniversitelerimizin etrafında kurulacak sosyal tesisler için özel sektöre bürokratik kolaylık sağlanmalı, mevcut potansiyel hakkında bilgi verilmelidir.

\section{Külttür Dersleri Müfredata Konmalı}

Tüm öğrenciler hangi bölümde olurlarsa olsunlar, ülkelerini ve dünyayı iyi anlamış genç aydınlar olarak mezun olmaları gerektiğine inanıyorum. 
Sosyal bir kimliğe kavuşma sürecindeki üniversite çağ gençliğine ihtiyaçları olan ( Türkiye koşullarında lise sürecinde edinilmesi mümkün olmayan) sosyal ve kültürel olgunluğu üniversitelerin vermesi zorunludur. Bu açıdan her üniversitede temel kültür dersi veya derslerin mecburi kılınması kaçınılmazdır. Mükemmel bir mühendislik için sıkı bir teknik temel eğitim alınmış olunması günümüzde yeterli değil. Bugün artık mühendislik öğrencisinin şu özelliklere sahip olması istenmektedir.

Yazılı ve sözlü açık/serbest iletişim kurabilmesi

Toplumsal rolünü anlayabilmesi

Etik sorumlulukların kavranması

İleri teknoloji toplumunda liderliğe hazırlanabilmesi

Bağımsız düşünebilme yetisi

Çağdaş vatandaşlar olarak toplumsal alanda etkili işlev görecek bilgi ve perspektifle donatılmış olmak.

Bu ihtiyacı göz önüne alan İstanbul Üniversitesi mühendislik eğitiminin \%20'sini İnsan ve Toplum Bilimleri derslerine ayırmıs ve bu derslerin koordinasyonu için Fen-Edebiyat fakültesi bünyesinde İnsan ve Toplum Bilimleri bölümünü kurmuştur. Buna benzer yapılanmalar öğrencilerin edebiyat, tarih, felsefe, sanat konularında bilgili, eleştirel düşünce üretebilen kişiler olarak topluma kazanması amacıyla 2023 üniversitelerimizin vizyonu içinde yerini almalı. Bunun en pratik yolunun Fen-Edebiyat Fakültelerinde bir kültür-servis bölümünün kurulması olabileceğini söyleyen akademisyenlerimize kulak verilmeli.

En çok münazaranın olması gerektiği ders olan Türk Dili dersinde bile öğrencilerin fikir alış-verişi yapmasından korkuluyor. Hoşlanmadığı ama geniş bir kesimin lider kabul ettiği bir şahsın bahsi geçince "adını duymak istemiyorum, bunun yeri burası değil" deyip dersine devam ediyor. Tartışmanın, kitleleri etkileyen olayların yorum yeri üniversite değil de neresidir. Karşı fikirlerin serbestçe tartışıldı̆̆ 1 yer olması gereken üniversitelerimizin hocaları ne kadar da açık fikirli. Oysa $A B D$ ve Avrupa ülkelerinde her türlü ideoloji, sonu -izm ile biten her türlü akım ders kitaplarında işleniyor ve derslerde tartışılıyor. Müfredata konulacak kültür dersleri bu açığı kapatır umudundayım.

Üniversitelerimiz dışarıda esen rüzgârlara kapalı durunca içinde fırtınalar eser, öğrenci grupları yandaş bulmak için saman atından su yürüten metotlar izlemeye devam eder.

\section{Teoride Öğrenilen Uygulamada Görülmeli.}

Dersler kapalı kapılar ardında uygulamadan uzak geçiyor. Erciyes Üniversitesinin düzenlediği "İ̈BF'lerin Geleceği” adlı sempozyumda bu soruna çare olarak üniversite öğrencilerinin sanayi-üniversite işbirliğiyle 
dönem içinde de staj olanaklarının arttırılması gibi çözümler sunuluyor. Diğer fakülte öğrencilerinin de aynı dertten muzdarip olmaları çözüm önerilerini çeşitlendirmeyi gerekli kılıyor. Ankara Üniversitesi Eğitim Fakültesi öğrencisi teoride öğrendiğini uygulamak için stajını, tıp fakültesine bağlı hastaneler uygulaması gibi, eğitim fakültesine bağlı ilkokul veya liselerde yapmalıdır. 2023'ün temel eğitimi, üniversite kampüslerinde veya yakınında kurulan okullarda, alanında uzman akademisyenler gözetimindeki üniversitelilerce neden verilmesin?. Hukuk Fakültesi öğrencisi de daha çok "kurgu mahkeme" ile hâkim, savcı, avukat olma heyecanını atlatmak, bilgilerini "karar" için kullanmak istiyor. Makine, elektrik mühendisliği öğrencileri laboratuarlarda uygulama derslerinin arttırılmasıyla proje üretmek, kafalarında kurguladıklarını elle tutulur hale getirmek istiyorlar. Siyasal Bilgiler Fakültesi öğrencileri, yüzyıllar önce çizilen para-arz talep eğrilerini ezbere biliyorlar ancak 2001 krizi nedenleri sonuçları üzerinde yorum yapamıyorlar. Derste anlatılan teoriler, kuramlar gerçek hayattan örneklerle anlaşılır ve uygulanabilir hale getirilmekten ziyade, ezberletiliyor. SBF öğrencileri, fikirlerin özgürce paylaşılacağı dersler ve konferansların sayısının ve içeriğinin arttırılmasını istiyor. Atatürk'ün eğitim üzerine düşüncesi, eksikliğimiz hususunda bizi yillar öncesinden uyarır nitelikte. Onun tanımladığı eğitim 'aktif katılımı' gerektirir. Aktif katılım:

\section{Uygulamalı eğitim,}

2. Eğitimde eğitilenin de tenkit edebilme hakkının yalnız olması değil, bunun teşvik edilmesi gereği,

3. Tüm eğitimin disiplinli bir şekilde yapılarak ehliyetsizce, yeteneksizce, kendi terimiyle kıymetsizce acımadan sistemden elenmesi şartlarını içerir.

Öğretim görevlileri hızla değişen gündeme ayak uydurmalı ve her türlü fikrin tartışlabileceğini amfi dersler düzenlenmeli. Bir yerlerde yalan tarih yazılıyor, sınırlar çiziliyor, doğal kaynaklar paylaşılıyor; bizim hocalarımız hala yüzyıl önce yayınlanan kimsenin okumadığ 1 "milletlerin zenginliğii" kitabının yazarı Adam Smith'in ezberledikleri cümlelerini yinelemekten öte örnek vermeden derslerini bitirip, çekip gidiyorlar.

ABD'de açık kitap sınav yapılıyor. Sınav soruları öğrencilerin öğrendiklerini nasıl yorumladıklarını anlamaya yönelik. Bizim öğretim görevlerimizin soruları kitapta yazılı paragraflar olduğu için kitapları bizden iki metre uzaklaştırmamızı istiyorlar. Hukuk Fakültesi öğrencileri 'vicdan' ve 'usul' arasında kaldıklarında ne yapmaları gerektiğini, adaletin nasıl sağlanacağını, adalet sağlanırken yaratılan adaletsizliği nasıl çözeceklerini öğrenmek istiyorlar. Eğitim Fakültesi öğrencisi uyum zorluğu çeken bir öğrenciye nasıl yaklaşacağını böyle bir çocukla karşılaşmadan kitaplardan öğrenemez, ona teorileri ezberletmenin faydası yoktur. 


\section{Üniversite-Sanayi İşbirliği}

Sanayici uzun bir süre AR-GE eksikliklerini 'know-how' tekniğiyle ve ithal edilen patentlerle kapatmaya çalıştı. Üniversite sanayi ortaklığının arttırılması amaçlı toplantıda yapıcı kararlar alındı. Üniversiteler sanayiciden ne istediklerini anlatt1.

- Teknoloji değerlendirme ortak merkezi ile araştırma fonları kurularak işbirliği sağlansın.

- Labaratuvarların ortak kullanım ilkesi belirlensin. Teknoparklarla işbirliği imkanları oluşturularak veri ve bilgi bankaları kurulsun.

- Üniversite öğretim üyelerine sanayi de çalışma imkanı verilsin.

Uygulama eksikliğinden yakınan üniversite öğrencileri, üniversitesanayi işbirliği sağlandığı zaman sanayi de staj yapma, projelerine kaynak bulma gibi faydalar elde edecektir. Öğretim görevlileri, sene sonu proje çalışmalarından mekan ve kaynak sıkıntısı çeken öğrencilerinin şikayetlerini organize sanayiye ilettiklerinde ilgiyle karşılanmamaları, sanayicilerin dışarı akıttıkları paralarının bir kısmını üniversitelere hibe etmekten kaçınmaları, üniversite öğrencisinin gerçek hayatı tanımasını geciktiriyor. Bu manzarada üniversitelerin sanayiciler açısından cazip hale gelmesi için bazı düzenlemelere gitmesi gerekiyor.

- Hizmetlerini anlatacakları periyodik yayınlar sanayi kuruluşlarına duyurulmalı, onların anlayacağı dilden konuşulmalıdır.

- Üniversite, bünyesinde kuracağı birimlerle, üniversite-sanayi sorularına nerede-nasıl çözüm bulacağını öğrenmelidir.

- En önemli işbirliği AR-GE alanında olmalı. Üniversiteler pratikte kullanılmayacak teknolojiler yerine sanayinin uygulayabileceği teknolojiler geliştirilmelidir.

2023 y1lı bilim-teknoloji vizyonunda mutlaka bu konu derinlemesine incelenmelidir. Üniversite-sanayi işbirliği, üniversitelerin bilim politikası belirlemesinde finansal yardım sağlaması bakımından gerekli yapılanmalardır. Kaynağı üniversiteler olan milli bilgi sınıfı önderliğinde Türk milletinin sahip olduğu engin ve derin maddi-manevi potansiyeli; eğitilmiş emek, akıllıca yönlendirilmiş sermaye, özümsenmiş bilgi ile işlenerek kullanılmalı ve böylece muasır medeniyetler seviyesine varma yolundaki adımlarımız hız kazanmalı.

\section{Yüksek Öğretimin Özerkliği}

Yüksek öğretim sisteminin en önemli ayaklarından biri kuşkusuz üniversitenin özerk olmasıdır. Özerk üniversitenin, öğrencinin barınma, sosyal güvence, sosyal tesis ve burs gibi ihtiyaçlarını katı bir merkezi yapılanmaya göre daha kolay ve hızlı karşılayacağı aşikardır.. Bitmeyen ihtiyaçlar ancak yenilikçi, dinamik yapılı üniversiteler sayesinde karşılanır. 
O nedenle yenilikçiliğin sağlanabilmesinin yolu da üniversitelere güvenmekten ve onların kurumsal özerkliklerini yüksek tutacak ve koruyacak tedbirler almaktan, hukuki düzenlemeleri her türlü politik kaygıdan uzak yapmaktan geçiyor.

Atatürk, Cumhuriyetin ilanından sonra Darülfünun ile ilgilenmeye başladı. Sonuçta Darülfünun kapatılıp onun yerine 2252 Sayılı Kanun ile İstanbul Üniversitesi kurulmuştur. Bu Kanun, ülkemizde çağdaş üniversitelerin kurulması sürecinin başlangıcı olmuştur. İstanbul Üniversitesi'ni, İstanbul Teknik Üniversitesi ile Ankara Üniversitesi izlemiştir. Üniversitelere 4436 Sayılı Kanunla muhtariyet (özerklik) verilmiştir.

Ancak, maalesef bu özerklik sadece kağıt üstünde kalmış, uygulamada özerklikten uzak kalınmıştır.

Üniversitelerin özerk oluşlarının ölçütleri nelerdir veya neler olmalıdır?

1. Gayri Menkul ve diğer donanımların mülkiyetine sahip olmak

2. Borçlanarak fon oluşturabilmek bilmek

3. Yaratılan kaynakları, kendi amaçları doğrultusunda bağımsız harcaya

4. Akademik program ve ders içeriklerini belirleyebilmek

5. Akademik personelin ise alınmasına ve işten çıkarılmasına karar verebilmek

6. Çalışanların ücretlerini belirleyebilmek

7. Öğrenci kontenjanlarını belirleyebilmek

8. Öğrenci harçlarını belirleyebilmek

9. Öğretim elemanlarının diğer kurum ve kuruluşların düzenledikleri panel, sempozyum, açık oturum ve şura gibi etkinliklere katılabilmeleri

$\mathrm{Bu}$ ölçütler dikkate alındığında üniversitelerimizin tam özerk olduklarını söylemek güçtür.

Gerçek anlamda özerk olmak, üniversitenin kendi kaynaklarını yaratmalarına bağlıdır. Üniversitelerin araştırma merkezlerine etkinlik kazandıracak mali ve idari özerklik hangi şekilde olursa olsun sağlanırsa; üniversiteler kendi bilim politikasına göre bütçe yapan, ulusal ve uluslararası bilim kuruluşlarıyla organik bağ kurarlar. Bu şekilde üniversitelerimiz bilimsel çalışma yapılabilecek daha cazip kurumlar haline gelir. 'Bana çalışabileceğim ortam verilsin burada aldığım maaşın yarısını almaya hazırım' görüşünde olan yurt dışındaki bilim adamlarımızın dönüşü için büyük bir adım atılmış olunur. 
YÖK Yasası mutlaka üniversite dinamikleri etrafında, ön yargıdan uzak tartışılsın. Bugünün dünyası, gerçek bilim ve teknoloji üretme bilinci üzerine kuruludur ve daha nice 100 yıllar görmek ümidindeki Türkiye Cumhuriyeti, üniversitelerin asıl fonksiyonlarını yapamaz hale getiren iç karışıklıklardan bir an evvel kurtarmalıdır.

O nedenle üniversitelerimizin özerkliklerini kazanabilmeleri için çalışmak ve bunun için alınması gereken bütün önlemleri almak gerekir.

\section{3'te Eğitimde Yeni Düzenlemeler}

Diplomasını alıp hayata atılmaya niyetlenen genç için mükemmellik tabirini kullanmak, bilim ve teknolojideki hızlı ve kapsamlı gelişmeler her alanda sürekli değişim yarattığı için hala çok yerinde değildir. İlgi ve yeteneklerine en uygun alana yerleşmiş, en son teknolojinin imkanları kullanılarak eğitim görmüş, politik-sosyolojik-ekonomik-sanatsal gündem olaylarına ilişkin fikir üretebilen, dil becerisine hakim mezunlar yetiştirme hedefimizde başarılı olsak bile bu, her șeyin hallolduğu anlamına gelmez. Dünyada yaşanan değişimler, küreselleşme ve $\mathrm{AB}$ süreci, bireylerin her düzeyde eğitim ve öğrenme ihtiyacındaki değişimi ortaya koymakta, eğitim sisteminde düzenlemelerin gerekliliğini vurgulamaktadır. Bu bağlamda 17. Milli Eğitim Şurası ön komisyon çalışmaları küreselleşme ve AB sürecinde Türk Milli Eğitim sistemi gündem maddesi;

- Yaşam boyu öğrenme

- Eğitimde hareketlilik

- Eğitimde nitelik olarak üç başlık halinde ele alınmıştır.

Yaşam Boyu Öğrenme: Bireyin, sosyal ve/veya istihdama ilişkin bir perspektif içinde bilgi, beceri ve yeteneklerini geliştirme amacına yönelik olarak yaşam boyunca gerçekleştirdiği tüm öğrenme faaliyetleridir. AB ülkelerinin hedefi 2010 yılına kadar yaşam boyu öğrenmeye katılım oranı, çalışan yetişkin nüfus için en az \%15 olması ve hiçbir ülkede \%10'dan az olmamasıdır. Ancak Türkiye'de bu oran henüz \%1,1'dir. Böylesine hızlı değişim karşısında ihtiyaçların en kısa sürede ve en etkin şekilde karşılanması için yaşam boyu eğitim, bir çözüm yolu olarak ortaya çıkmaktadır. Her alanda okul açmak mümkün olmadığından okul dışı eğitim olarak tanınan yaşam boyu eğitim programlarına başvurulmalıdır. Atatürk, "Milli kültürümüzü, muasır medeniyetler seviyesinin üzerine çıkaracağız." cümlesiyle dile getirdiği hedefi doğrultusunda istediği eğitimin yaşam boyu sürmesidir.

Yaşam boyu eğitim, gencin üniversitelerimizde edinemediği bilgileri ve yetileri, meslek içi kurslarla, üniversite akşam kurslarıyla telafi etmesini öngörüyor.

Eğitimde Hareketlilik: Yüksek öğretim düzeyinde özellikle bilim adamı yetiştirme çerçevesinde çoğunluğu YÖK tarafından farklı ülkelere 
bilim adamı adayları gönderilmiş ve bu çerçevede bir hareketlilik mevcuttur. Ancak, son yıllarda yurt dışına gönderilen akademisyen adaylarının dönüş oranlarında dikkat çekici azalmalar görülmektedir. Bunun önlenmesine yönelik tedbirlere ihtiyaç vardır. Hareketliliği sağlayacak oluşumlar Socrates/Erasmus, Leonardo da Vinci, Erasmus, Mundus ve Gençlik programları olarak sinıflandırılmaktadır.

Türkiye, $\mathrm{AB}$ politikaları ile programları arasındaki yakın ilişkiyi dikkate alarak bu programlara tam ve etkin katılım için çaba göstermektedir. Temennimiz, bu değişim sayısının ülke genelinde arttırılması, değişim sayısı az olan yüksek öğretim kurumlarına önem verilmesi, Erasmus projelerinin tanıtımına önem verilmesidir. Erasmusa katılım talebi artarsa öğrenci, projenin kıstaslarını yerine getirmek için (belli seviyede dil bilgisi, not ortalaması) kendini geliştirecek, daha çok çalışacaktır.

Ĕgitimde Nitelik: Eğitimde nitelik, eğitim veren kişi ve kuruluşların daha iyi hale getirilmesi anlamına geliyor. Eğitim fakültelerinin öğrenci kontenjanlarının saptanmasında ülkenin kısa ve uzun vadeli gereksinimleri göz önüne alınmalıdır. Çünkü ilk bölümde ele aldığım orta öğretim sisteminin düzeltilmesi aşamasında donanımlı eğitimcilere ihtiyaç duyulacaktır. Gene ÖSS'nin seçiciliğinin arttırılması yolunda öğretmenlik programlarına girişte akademik başarının yanı sıra öğretmenlik niteliklerinin gerektirdiği kişisel niteliklerin ölçülmesine yönelik mekanizmalar geliştirilmelidir. Gerekli ihtiyaç analizleri yapılmadan, mevcut alt yapı ve öğretim kadroları oluşturulmadan yeni eğitim fakülteleri açılmamalıdır.

Akademik personel ihtiyacının karşılanması amacıyla açılan yüksek lisans, doktora programlarında nitelikli araştırmacı yetiştirmek için yeni kanuni düzenlemelere gidilmelidir. Doktora ve tez çalışmalarını belli kıstaslara bağlanacak bu düzenlemelerle, kaliteyi yakalamak için sadece kendini kanıtlamış üniversitelerimizde bu programların açılmasına müsaade etmek gerekir. Ayrıca yurt dışı yüksek lisans öğreniminde maliyetleri ve beyin göçüyle kayıpları en aza indirmek için önlemler alınmalıdır.

Üniversitelerimizin akademik personel sıkıntısı için bu ihtiyaç karşılanırken plansız hareket etmek, kaş yapayım derken göz çıkarır. Bu meslek hak ettiği saygınlığa ulaşırsa üniversitelerimizde kaliteli yayın da yayınlara atıf da artar. Ne var ki gençler artık yüksek lisans yapmak istemiyor. Akademisyen olma istidadındaki öğrenciler için her an arayış içinde olunmalı. Konferanslarda katılımcı, ödevlerinde araştırmacı, derslerde sorgulayıcı ve sınavlarında başarılı öğrenciler, öğretim üyelerince akademisyenliğe özendirilmeli. Bu hususta bunlara teşvik bursları verilebilir, konferanslara katılmaları için okulu temsilen gitmek onuru verilerek heveslendirilebilinir. Koç Üniversitesi Elektrik-Elektronik Mühendisliği'nde öğrenci yüksek lisans yapmaya hocasının laboratuarda kendisine eşlik etmesini istemesiyle karar verir. Dolayısıyla akademisyen olmak biraz da gönül işidir. 


\section{SONUÇ}

Üniversite gerçeğimizi sorgularken çoğu zaman tepeden bakan bir yaklaşım sergiliyoruz. Oysa ki üniversiteleri dolduran biz gençlerin, üniversiteye hazırlanışta başlayan sorunları, yerleşirken devam ediyor. Üniversitede okurken de ayrı bir boyut kazanıyor.

Üniversite gençliği kimliğini sorguluyor. Dersleri ezberleyip geçmekten ziyade, toplumu bir parçası olmak için fikrini anlatmak, projelerini sergilemek, bildiğini uygulamak, farklı şeyler denemek, deneyip beğendiği alanda üretim yapmak istiyor. Bunun için yarış atı gibi hazırlanıp bir şekilde yerleștiği üniversitesinde, teknolojik sistemlerle kısa zamanda öğrenilir hale gelmiş derslerini öğrendikten sonra başka alanlarda da kendini eğitmek istiyor. Bilginin hızla eskidiği dünyaya böylece daha kolay ayak uydurmak istiyor.

Türkiye Cumhuriyeti, eskiden kalma kavgaların rövanşını oynayıp durmayı bırakmalı. Geleceğini temsil eden gençlerle geleceğe yüzünü çevirmeli. En seçkin öğrencilerle, en seçkin hocaları bulușturup sanayinin ve devletin desteğiyle teknoparklarda, düşünce derneklerinde, konferanslarda bilimsel ve felsefi çalışmalar yapmalıdır. Bunun hayata geçeceği günler için bugünden üniversitelerimizi durağanlıktan kurtaracak, değişimin hızına ayak uyduracak yapılanmalarla donatmalıyız. Bu uğurda vakit kaybetmeden kısa veya uzun vadede getirisi olan her türlü yapılanmayı üniversitelerimizde içselleştirmeliyiz. 2023'te dünyada da artan yüksek öğretim talebini ülkemiz üniversitelerinin karşılamaması için hiçbir neden yok.

Atatürk'ün dediği gibi "Eğitim bir milleti ya hür, bağımsız şanlı, yüce bir toplum olarak yaşatır ya da bir milleti açlığa ve sefalete terk eder." 2023' te dileğimiz ülkemizin hür, esnek, çağdaş bir ortamda kültürüne sahip çıkan, araştıran, sorgulayan, uygulayan, dinleyen, söyleyen, gelişmelere açık bir gençlik yetiştirmesi ve kendisini yüce bir toplum haline getirmesidir. 